\title{
Millettia aboensis Attenuates Diabetes Induced Systemic Oxidative Stress in Experimental Animal Model
}

\author{
Daniel Lotanna Ajaghaku' ${ }^{1 *}$, Obiora Celestine Ugwu ${ }^{1}$, Njideka Ifeoma Ani ${ }^{1}$, Uchechukwu Harrison Orji ${ }^{2}$, Raymond \\ Ogbonna Offiah ${ }^{3}$ and Amara Anwuchaepe Ajaghaku ${ }^{4}$
}

${ }^{1}$ Department of Pharmacology, Enugu State University of Science and Technology, Nigeria

${ }^{2}$ Department of Pharmacology and Toxicology, Nnamdi Azikiwe University, Awka, Nigeria

${ }^{3}$ Department of Pharmacology and Therapeutics, Enugu State University of Science and Technology, Nigeria

${ }^{4}$ Department of Pharmacognosy, Enugu State University of Science and Technology, Nigeria

Submission: May 03, 2021; Published: May 18, 2021

*Corresponding author: Daniel Lotanna Ajaghaku, Department of Pharmacology, Faculty of Pharmaceutical Sciences, Enugu State University of Science and Technology, Enugu State, Nigeria

Abstract

Millettia aboensis has both antioxidant and antihyperglycermic potentials. However, no scientific studies have investigated its effect on diabetes induced systemic oxidative stress which is a major driving force of diabetic complications. This study evaluated the effect of $M$. aboensis on diabetes induced systemic oxidative stress in experimental animal model. Diabetes was induced with $70 \mathrm{mg} / \mathrm{kg}$ streptozotocin (i.p) following 30 minutes pre-administration of $50 \mathrm{mg} / \mathrm{kg}$ nicotinamide (i.p). Diabetic rats were treated orally with $200,300 \mathrm{and} 400 \mathrm{mg} / \mathrm{kg}$ of the extract and fractions for 21 days. Fasting blood glucose was determined every 7 days while blood samples were collected on the 22nd day for the determination of antioxidant enzymes and total antioxidant status. The extract showed significant $(\mathrm{p}<0.05)$ reduction in blood glucose at 400 $\mathrm{mg} / \mathrm{kg}$ from the $14^{\text {th }}$ day of treatment while the ethyl acetate fraction at $300 \mathrm{mg} / \mathrm{kg}$ showed significant $(\mathrm{p}<0.05)$ effect from the $7^{\text {th }}$ day of treatment. Treatment with the extract, ethyl acetate and butanol fraction at all doses showed significant $(\mathrm{p}<0.05)$ increase in catalase enzyme activity compared with the diabetes induced control group. Ethyl acetate fraction at all doses also showed significant $(\mathrm{p}<0.05)$ increase in superoxide dismutase enzyme activity and total antioxidant capacity. This study validated the antihyperglycermic effect of M. aboensis as well as established the ability of this plant extract and fractions to attenuate diabetes induced oxidative stress. M. aboensis may be of therapeutic importance in the management of both hyperglycermia and oxidative damage associated with diabetes.

Keywords: M aboensis; Diabetes, Oxidative stress; Antihyperglycermic effect

\section{Background}

Diabetes mellitus is a metabolic disorder characterized by chronic hyperglycemia. Defects in insulin secretion and/or insulin action are common factors associated with all forms of diabetes [1]. Evidences from numerous scientific experiments have highlighted the correlation between oxidative stress and diabetes [2-4]. In vitro studies with pancreatic beta cells have also provided evidence for an increased reactive oxygen species production in diabetes [5-7]. Hyperglycermia contributes not only to increased free radical generation but has also been established to attenuate enzymatic and non-enzymatic antioxidant mechanisms $[8,9]$. Due to the highly reactive nature of free radicals, they directly oxidize and damage DNA, proteins and lipids [10]. Increased free radical formation in the absence of appropriate compensatory antioxidant defence mechanism predisposes to oxidative stress. Hyperglycermia-induced oxidative stress is now recognised as the driving force for the development of diabetic complications [11]. Despite efforts to control blood glucose with current methods of treating diabetes, tissue and organ damages has been observed to keep accumulating over time in most diabetic patients [12]. The beneficial effect of targeting oxidative stress together with hyperglycermia has been reported in animal models of diabetes as well as in diabetic patients $[2,3]$.

In our previous studies, we reported that $M$. aboensis ameliorated site (liver) specific oxidative stress induced by carbon tetrachloride $\left(\mathrm{CCL}_{4}\right)$ [13]. The active principles in the extract were also shown to interact synergistically in scavenging 
free radicals [13]. On the other hand, the ability of the leaf extract of $M$. aboensis to reduce hyperglycermia in alloxan model of diabetes has been reported [14]. Its pancreatic protective effect has also been associated with its antidiabetic activity [14]. Given that $M$. aboensis has both antioxidant and antihyperglycermic potentials, it is expected that the combination of these effects may be beneficial in reducing complications associated with diabetes. However, no scientific studies have investigated the effect of this plant on diabetes induced systemic oxidative stress which is a major driving force of diabetic complications. To fill the gap in knowledge, this study evaluated the effect of M. aboensis on diabetes induced systemic oxidative stress in experimental animal model.

\section{Materials and Methods}

\section{Plant material}

The leaves of M. aboensis were collected from Nsukka, Enugu State, Nigeria and were authenticated by a taxonomist - Mr. Alfred Ozioko of Bioresource Development and Conservation Project, Nsukka, Enugu State, Nigeria. A voucher specimen has been deposited at the herbarium of the Department of Pharmacognosy, Faculty of Pharmaceutical Sciences, Nnamdi Azikiwe University, Awka, with the herbarium number PCG/474/A/021. The leaves were air dried and pulverized into coarse powder.

\section{Animals}

Wistar Albino rats (200 -250) were used for this study. The animals were obtained from the Animal House of the Department of Pharmacology/Toxicology, Nnamdi Azikiwe University, Awka. All animal experiments were conducted in compliance with $\mathrm{NIH}$ guide for care and use of laboratory animals.

\section{Extraction and fractionation}

The pulverized leaves were cold macerated in aqueous ethanol $(70 \%)$ for $48 \mathrm{~h}$ and the resulting solution was filtered and concentration in vacuo using rotary evaporator at $50^{\circ} \mathrm{C}$. Two-third of the ethanol extract was subjected to liquid-liquid partition successively with $2.5 \mathrm{~L}$ of n-hexane, ethyl acetate, and then butanol to give different fractions soluble in these solvents. The fractions were concentrated using rotary evaporator at $50^{\circ} \mathrm{C}$ and stored at $4^{\circ} \mathrm{C}$.

\section{Diabetes induced systemic oxidative stress}

Albino rats $(n=100)$ were fasted overnight for $12 \mathrm{~h}$ and fasting blood glucose levels taken from tail vein using Accu-check Glucometer (Roche, Germany) before the induction of diabetes with $70 \mathrm{mg} / \mathrm{kg}$ STZ (i.p) following 30 minis pre-administration with $50 \mathrm{mg} / \mathrm{kg}$ NAD (i.p). After $72 \mathrm{~h}$, animals with fasting blood glucose levels $>160 \mathrm{mg} / \mathrm{dl}$ were confirmed diabetic and selected for the study. The animals were grouped into fifteen groups of six animals each. Groups 1 - 3 received the extract, groups 4 - 6 n-hexane fraction, groups 7 - 9 ethyl acetate fraction and groups
10 - 12 butanol fraction at the oral doses of 200, 300 and 400 $\mathrm{mg} / \mathrm{kg}$ respectively. The control groups (13 and 14) received 5 $\mathrm{mg} / \mathrm{kg}$ glibenclamide and $5 \mathrm{~mL} / \mathrm{kg}$ 5\% Tween 20 respectively. Diabetes was not induced in the 15 th group but received $5 \mathrm{~mL} / \mathrm{kg}$ $5 \%$ Tween 20 . Treatment with the extract and fractions continued for 21 days with fasting blood glucose determined every 7 days. On the $22^{\text {nd }}$ day, blood samples were collected through retroorbital plexus into a plain tube. The sera obtained were used for the determination of antioxidant enzymes and total antioxidant status.

\section{Determination of antioxidant enzyme activity}

Superoxide dismutase activity was determined by its ability to inhibit the auto-oxidation of epinephrine determined by the increase in absorbance at $480 \mathrm{~nm}$ as described by Sun \& Zigma [15] while catalase activity monitored by the disappearance of $\mathrm{H}_{2} \mathrm{O}_{2}$ determined according to the method of Beers and Sizer as described by Usoh et al. [16].

\section{Determination of serum total antioxidant capacity}

Total antioxidant capacity of the serum was determined using the method of Kampa et al. [17] based on the ability of antioxidants to inhibit the oxidation of 2,2-Azino-di-3-ethylbenzthiazoline sulphonate (ABTS) by metmyoglobin. Total antioxidant capacity was quantified as millimolar Trolox equivalents.

\section{Statistical analysis}

Results were expressed as Mean + SEM. Statistical analysis were done using one way ANOVA followed by posthoc multiple comparism using Turkey's test. Differences between means were considered significant at $\mathrm{P}<0.05$.

\section{Results}

\section{Effect of treatment on STZ-NAD induced hyperglycermia}

Hyperglycermia was observed in all groups $72 \mathrm{~h}$ post induction with STZ-NAD. This hyperglycermic state was maintained throughout the 21 days the study lasted (Figure 1). The extract at $400 \mathrm{mg} / \mathrm{kg}$ on the $14^{\text {th }}$ day after diabetes induction produced significant $(\mathrm{p}<0.05)$ reduction of blood glucose while significant $(p<0.05)$ reduction was observed at all doses on the $21^{\text {st }}$ day. The ethyl acetate fraction at $300 \mathrm{mg} / \mathrm{kg}$ showed significant $(\mathrm{p}<0.05)$ reduction in blood glucose from the $7^{\text {th }}$ day when compared to vehicle control group (5\% Tween 20). At 300 and $400 \mathrm{mg} / \mathrm{kg}$, the ethyl acetate fraction produced significant $(\mathrm{p}<0.05)$ reduction in blood glucose compared with $72 \mathrm{~h}$ post-induction and control group (5\% tween 20) just like butanol fraction at $400 \mathrm{mg} / \mathrm{kg}$.

\section{Effect of treatment on oxidative stress}

Induction of diabetes produced significant $(\mathrm{p}<0.05)$ reduction in antioxidant enzymes activities as well as total antioxidant capacity compared to un-induced control group. The suppressed antioxidant enzymes and total antioxidant capacity were however 
elevated after treatment with the extract and fractions of $M$. aboensis (Table 1). Treatment with the extract, ethyl acetate and butanol fraction at all doses showed significant $(\mathrm{p}<0.05)$ increase in catalase enzyme activity compared with the diabetes induced control group. Ethyl acetate fraction at all doses also showed significant $(\mathrm{p}<0.05)$ increase in superoxide dismutase enzyme activity and total antioxidant capacity while the extract and butanol fraction only showed significant $(\mathrm{p}<0.05)$ effect at 300 and $400 \mathrm{mg} / \mathrm{kg}$ compared with the diabetes induced control group.
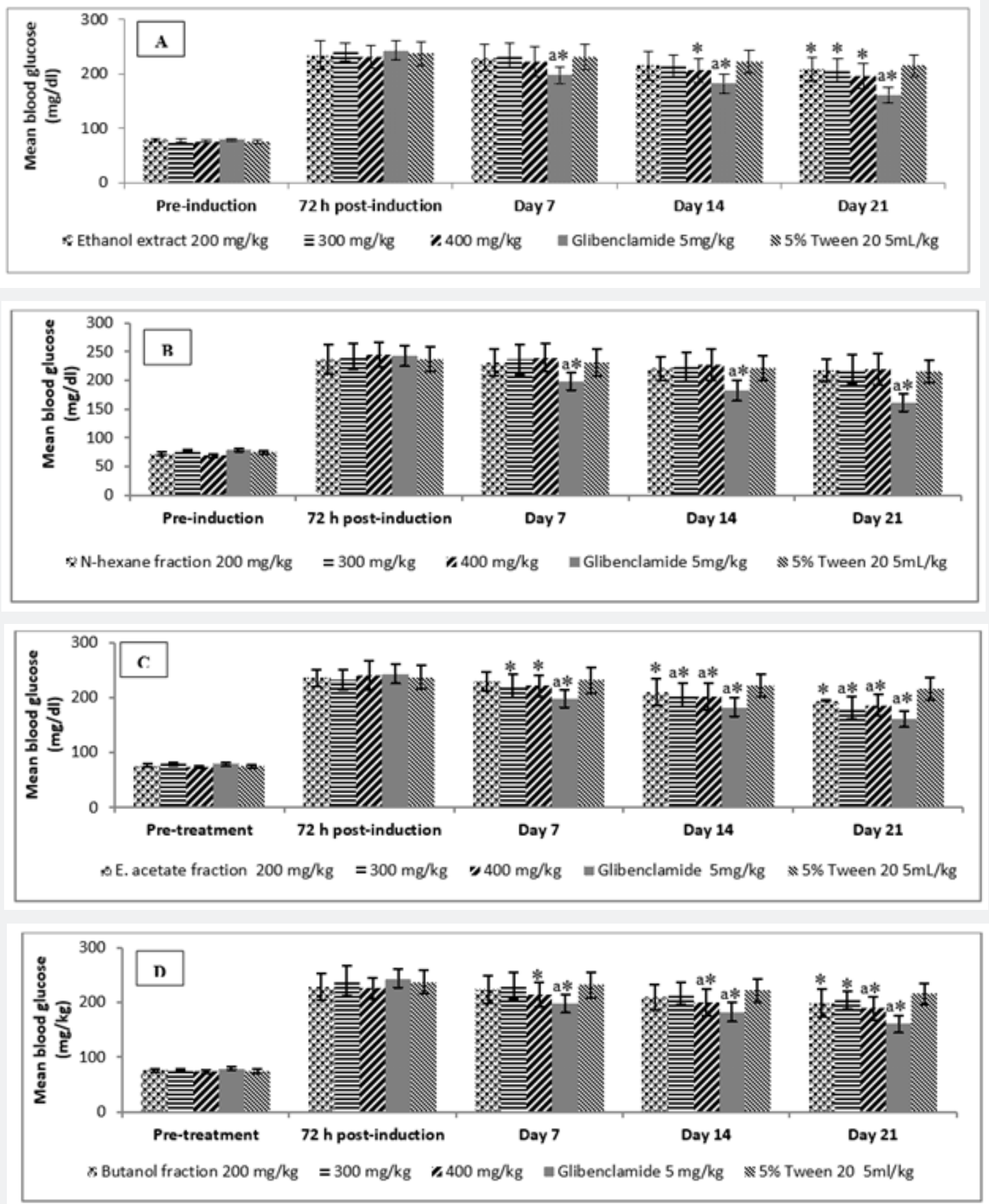

Figure 1: Effect of the extract and fractions on STZ-NAD induced hyperglycemia $\mathrm{N}=6$, a $\mathrm{p}<0.05$ compared with $72 \mathrm{~h}$ post-induction, ${ }^{*} \mathrm{p}<$ 0.05 compared with $5 \%$ Tween $20 . A=$ Ethanol extract, $B=N$-hexane fraction, $C=$ Ethyl acetate fraction, $D=$ Butanol fraction. 


\section{Current Research in Diabetes \& Obesity Journal}

Table 1: Effect of extract and fractions on serum antioxidant enzymes and total antioxidant capacity.

\begin{tabular}{|c|c|c|c|c|}
\hline Treatment & Dose (mg/kg) & CAT (U/mL) & SOD $(\mathrm{U} / \mathrm{mL})$ & TAC (mM) TE \\
\hline \multirow{3}{*}{ Ethanol Ext } & 200 & $6.1+0.1^{*}$ & $3.0+0.5$ & $0.55+0.04$ \\
\hline & 300 & $6.5+0.4^{*}$ & $3.5+0.3^{*}$ & $0.72+0.05^{*}$ \\
\hline & 400 & $6.7+0.8^{*}$ & $3.6+0.5^{*}$ & $0.79+0.03^{*}$ \\
\hline \multirow{3}{*}{ N-Hexane F. } & 200 & $3.5+0.2$ & $2.6+0.8$ & $0.45+0.04$ \\
\hline & 300 & $3.9+0.5$ & $2.6+0.5$ & $0.46+0.02$ \\
\hline & 400 & $4.1+0.9$ & $2.9+0.9$ & $0.51+0.06$ \\
\hline \multirow{3}{*}{ Ethyl acetate F. } & 200 & $6.5+0.3^{*}$ & $3.5+0.6^{*}$ & $0.91+0.02^{*}$ \\
\hline & 300 & $6.8+0.2^{*}$ & $3.8+0.2^{*}$ & $0.96+0.03^{*}$ \\
\hline & 400 & $7.2+0.6^{*}$ & $3.8+0.4^{*}$ & $1.08+0.01^{*}$ \\
\hline \multirow{2}{*}{ Butanol F. } & 200 & $6.5+0.4^{*}$ & $3.2+0.7$ & $0.56+0.05$ \\
\hline & 400 & $6.8+0.5^{*}$ & $3.7+0.4^{*}$ & $0.81+0.04^{*}$ \\
\hline Glibenclamide & 5 & $6.9+0.6^{*}$ & $3.9+0.7^{*}$ & $1.21+0.04^{*}$ \\
\hline $5 \%$ tween 20 & $5 \mathrm{ml} / \mathrm{kg}$ & $3.6+0.5$ & $2.7+0.5$ & $0.42+0.03$ \\
\hline $5 \%$ Tween 20 (uninduced) & $5 \mathrm{ml} / \mathrm{kg}$ & $12.4+0.7^{*}$ & $7.5+0.4^{*}$ & $3.96+0.10^{*}$ \\
\hline
\end{tabular}

$\mathrm{n}=6,{ }^{*} \mathrm{p}<0.05$ compared with control (5\% tween 20$)$, Ext: Extract, F: Fraction, CAT: Catalase, SOD: Superoxide Dismutase, TAC: Total Antioxidant Capacity, TE: Trolox Equivalent

\section{Discussion}

Several studies have demonstrated that oxidative stress plays an important role in the pathogenesis of diabetes complications ranging from stroke, neuropathy, retinopathy, nephropathy to cardiomyopathy [11]. In these pathological conditions, hyperglycermia has been seen as causal link between diabetes and increased oxidative stress [9]. Many biochemical pathways strictly associated with hyperglycemia, such as glucose autooxidation, polyol pathway, prostanoid synthesis and protein glycation increases ROS production [18]. Thus, maintaining adequate glucose level in diabetic condition is necessary for combating oxidative stress. The elevation of blood glucose above $160 \mathrm{mg} / \mathrm{dl}$ post administration of STZ-NAD was an indication of hyperglycermia associated with the combination of these agents. STZ is known to cause pancreatic $\beta$-cell damage whereas NAD partially protects insulin secreting cells against STZ complete damage [19]. STZ-NAD diabetes induction therefore mimics type II diabetes mellitus. The reduction in blood glucose by Millettia aboensis may be associated with its phytocompounds. In our previous study, two procyanidins- cathechin and epicathechin were isolated from the ethyl acetate fraction of M. aboensis [13] which happens to also be the most active antidiabetic fraction in this study. Procyanidines have shown antidiabetic activity in different glucose homeostasis disruption experimental models [20]. Their insulin mimetic effect on the liver and peripheral tissues has been documented as well as improvement of insulin expression in pancreatic $\beta$-cell [21-22]. Other mechanism of antidiabetic activity recorded for this class of phenolic compounds include but not limited to improvement of insulin expression in pancreatic $\beta$-cell, deceased $\beta$-cell apoptosis, increased glucose uptake and utilization in muscle and liver [20]. Decreased gluconeogenesis and glycogenolysis in the liver have also been reported with extracts rich in procyanidines [23]. The presence of this phytocompound in M. aboensis may be responsible for its reduction of blood glucose and may account for the differential activity of the fractions of the extract. Reduction in serum superoxide dismutase and catalase antioxidant enzyme activities as well as serum total antioxidant capacity were indications of compromised systemic oxidative stress following STZ-NAD induced diabetes. These findings were in agreement with other studies that have reported reduction in antioxidant enzymes as a major contributor to oxidative stress in diabetes $[9,11]$. Improvement in complications of diabetes has been observed following treatment with antioxidants providing evidence that these complications are associated with antioxidant deficiency [24]. Similarly, the therapeutic potentials of improved antioxidant enzyme in diabetic conditions was also demonstrated in studies that showed that over expression of antioxidant enzymes in STZ-treated transgenic mice attenuated the onset of diabetic complications [4]. The improvement in total antioxidant capacity and increased antioxidant enzymes following treatment with extract and fractions of M. aboensis is an indication of their ability to attenuate oxidative stress associated with STZ-NAD induced diabetes. This improved oxidative stress is expected to contribute to their beneficial effect in the management of hyperglycaemia associated with diabetes and other diabetic pathological complications mediated through oxidative stress.

Phenolic compounds particularly catechins have been found to increase plasma total antioxidant capacity, attenuated stress- 
sensitive signalling pathways and prooxidant enzymes and as well a known inducer of antioxidant enzymes like catalase and superoxidase dismutase [25]. Similarly, there are increasing evidences that as antioxidants, polyphenols protect cell constituents against oxidative damage and therefore through such means limit the risk of disease conditions associated with oxidative stress [26]. Pandey \& Rizvi [27] also found that consumption of antioxidants has been associated with reduced levels of systemic oxidative damages. We have previously reported that this plant exhibited site specific oxidative stress on $\mathrm{CCL}_{4}$ induced liver oxidative stress [13]. The isolated procyanidines were also reported to act in synergy. These same compounds may have also mediated the attenuation of systemic oxidative stress resulting from STZ-NAD induced diabetes.

\section{Conclusion}

This study validated the antihyperglycermic effect of $M$. aboensis as well as established the ability of this plant extract and fractions to attenuate diabetes induced oxidative stress. Since oxidative stress mediates most end organ damage and complications of diabetes, M. aboensis may be of therapeutic importance in the management of both hyperglycermia and oxidative damage associated with diabetes.

\section{References}

1. American Diabetes Association (2009) Diagnosis and Classification of Diabetes Mellitus. Diabetes Care 32(1): S62-S67.

2. Rosen P, Nawroth PP, King G, Moller W, Tritschler J, et al. (2001) The role of oxidative stress in the onset and progression of diabetes and its complications: a summary of a Congress Series sponsored by UNESCOMCBN, the American Diabetes Association and the German Diabetes Society. Diabetes/Metabolism Research and Reviews 17(3): 189-212.

3. Chikezie PC, Ojiako O, Ogbuji AC (2015) Oxidative Stress in Diabetes Mellitus. International Journal of Biological Chemistry, 9(3): 92-109.

4. Giacco, F, Brownlee M (2010) Oxidative stress and diabetic complications. Circulation research 107(9): 1058-1070.

5. Wang J, Wang H (2017) Oxidative Stress in Pancreatic Beta Cell Regeneration. Oxidative Medicine and Cellular Longevity, 1930261.

6. Eguchi N, Vaziri ND, Dafoe DC, Ichi H (2021) The Role of Oxidative Stress in Pancreatic $\beta$ Cell Dysfunction in Diabetes. International Journal of Molecular Sciences 22: 1509.

7. Newsholme P, Keane KN, Carlessi R, Cruzat V (2019) Oxidative stress pathways in pancreatic -cells and insulin-sensitive cells and tissues: importance to cell metabolism, function, and dysfunction. American Journal of Physiology-Cell Physiology 317: C420-C433.

8. Ramalingam S, Karuppiah M, Thiruppathi M, Palanivelu S, Panchanatham S (2020) Antioxidant potential of biflavonoid attenuates hyperglycemia by modulating the carbohydrate metabolic enzymes in high fat diet/streptozotocin induced diabetic rats. Redox Report 25(1): 1-10.

9. Matough FA, Budin SB, Hamid ZA, Alwahaibi N, Mohamed J (2012) The Role of Oxidative Stress and Antioxidants in Diabetic Complications. Sultan Qaboos University Medical Journal 12(1): 5-18.

10. Phaniendra A, Jestadi DB Periyasamy L (2015) Free Radicals:
Properties, Sources, Targets, and Their Implication in Various Diseases. Indian Journal of Clinical Biochemistry 30(1): 11-26.

11. Asmat U, Abad K, Ismail K (2016) Diabetes mellitus and oxidative stress-A concise review. Saudi Pharmaceutical Journal 24(5): 547-553.

12. Rask-Madsen C, King GL (2013) Vascular complications of diabetes: mechanisms of injury and protective factors. Cell Metabolism 17(1): 20-33.

13. Ajaghaku DL, Akah PA, Ilodigwe EE, Ajaghak AA, Onah CE, et al. (2020) Millettia aboensis ameliorates oxidative stress through synergic interaction of its active compounds. Journal of Complementary and Integrative Medicine 20190029.

14. Onyegeme-Okerenta BM, Essien EB (2015) Evaluation of anti-diabetic and anti-lipidemic activities of aqueous leaf extract of Millettia aboensis and its effects on pancreatic histology of alloxan-induced diabetic rats. Advances in Biochemistry 3(2): 24-29.

15. Sun M, Zigma S (1978) An improved spectrophotometer assay of superoxidant dismutase based on epinephrine antioxidation. Anal Biochem 90(1): 81-89.

16. Usoh IF, Akpan EJ, Etim EO, Farombi EO (2005) Antioxidant actions of dried flower extracts of Hibiscus sabdariffa. Pak J Nutr 4(3): 135-141.

17. Kampa M, Nistikaki A, Tsaousis V, Maliaraki N, Notas G, et al. (2002) A new automated method for the determination of the total antioxidant capacity (TAC) of human plasma, based on the crocin bleaching assay. BMC Clin Pathol 2(1): 3.

18. Busik JV, Mohr S, Grant MB (2008) Hyperglycemia-induced reactive oxygen species toxicity to endothelial cells is dependent on paracrine mediators. Diabetes 57(7): 1952-1965.

19. Mbagwu IS, Akah PA, Ajaghaku DL (2020) Newbouldia laevis improved glucose and fat homeostasis in a TYPE-2 diabesity mice model. J Ethnopharmacol 251:112555.

20. Gonzalez-Abuin N, Pinent M, Casanova-Marti A, Arola L, Blay M, et al. (2015) Procyanidins and their healthy protective effects against type 2 diabetes. Curr Med Chem 22(1): 39-50.

21. Pinent M, Blay M, Bladé MC, Salvadó MJ, Arola L, et al (2004) Grape seed-derived procyanidins have an antihyperglycemic effect in streptozotocin-induced diabetic rats and insulinomimetic activity in insulin-sensitive cell lines. Endocrinology 145(11): 4985-4990.

22. Yang K, Hashemi Z, Han W, Jin A, Yang H, et al. (2015) Hydrolysis enhances bioavailability of proanthocyanidin-derived metabolites and improves $\beta$-cell function in glucose intolerant rats. J Nutr Biochem 26(8): 850-859.

23. Hanhineva K, Törrönen R, Bondia-Pons I, Pekkinen J, Kolehmainen M, et al. (2010) Impact of dietary polyphenols on carbohydrate metabolism. International journal of molecular sciences 11(4): 1365-1402.

24. Ayepola OR, Brooks NL, Oguntibeju OO (2014) Oxidative Stress and Diabetic Complications: The Role of Antioxidant Vitamins and Flavonoids, Antioxidant-Antidiabetic Agents and Human Health, Intech Open.

25. Crespy V, Williamson G (2004) A review of the health effects of green tea catechins in in vivo animal models. Journal of Nutrition 134: 3431S-3440S.

26. Pandey KB, Rizvi SI (2010) Protective effect of resveratrol on markers of oxidative stress in human erythrocytes subjected to in vitro oxidative insult. Phytotherapeutic Research 24: S11-S14.

27. Pandey KB, Rizvi SI (2009) Plant polyphenols as dietary antioxidants in human health and disease. Oxidative Medicine and Cellular longevity 2(5): 270-278. 
(C) This work is licensed under Creative Commons Attribution 4.0 Licen BY DOI: 10.19080/CRDOJ.2021.14.555894

Your next submission with Juniper Publishers
will reach you the below assets
- Quality Editorial service
- Swift Peer Review
- Reprints availability
- E-prints Service
- Manuscript Podcast for convenient understanding
- Global attainment for your research
- Manuscript accessibility in different formats
( Pdf, E-pub, Full Text, Audio)
- Unceasing customer service
Track the below URL for one-step submission
https://juniperpublishers.com/online-submission.php

